\title{
BUSINESS AND POLITICS AT HOME AND ABROAD
}

\author{
By Gilbert H. Montague, \\ Counsellor-at-Law, New York.
}

In respect to industrial combinations, no civilized nation has muddled business with politics worse than the United States.

In American business and political life to-day, the most conspicuous factor is the campaign of Attorney-General Wickersham against the trusts. During the past three years, he has begun upwards of forty prosecutions under the Sherman Act-almost as many as were begun in the eight years of the Roosevelt administration, and nearly three times the total number begun by all the preceding administrations since the Sherman Act became law. During the past year, he has prosecuted suits under the Sherman Act against companies engaged in railway and steamship transportation, terminal facilities and tow-boat service, and against manufacturers and dealers in oil, tobacco, meat, groceries, butter, eggs, milk, sugar, paper, glass, powder, cotton, drugs, fertilizer, woolens, grain, box board, wall paper, lumber, coal, brick, steel, plumbing supplies, cash registers, coaster brakes, electrical appliances, shoe machinery, watch cases and kindling wood.

Edmund Burke exhorting Parliament on the eve of the American revolution to effect conciliation with America, declared that he did not know how to indict the whole American people. If he were alive to-day, he could learn from the Department of Justice.

Credible reports from Washington state that more than a thousand complaints against combinations in "restraint of trade" of commodities of all sorts, from telephones and wireless telegraphs to horseshoes and feather dusters, are now being investigated by the secret agents of the Department of Justice and that the department is now "being worked to its capacity." Recalling that the special appropriations for this work and for the enforcement of the Interstate Commerce Act have aggregated during the past nine years the enormous sum of $\$ 1,300,000$-more than one and one-half times the total amount paid annually in salaries to all the federal judges of the United States-Disraeli's epigram is realized: "The Government sinks into a police." 
This "police," under the absolute and uncontrolled direction of the administration, exerts its full strength to enforce upon business the economic theory which the Attorney-General imputes to the Sherman Act. What the theory of the Sherman Act is, no one clearly understands. After twenty years of perplexity and heart searching, the Supreme Court has pleasantly sprinkled over it the sweet savor of reasonableness. Competition may be "reasonably" restrained, but may not be "unreasonably" restrained. Competition may be "reasonably" carried on, but may not be "unreasonably" carried on. Within these indefinite and nebulous limits, opinion may honestly differ so widely as to what is and what is not unlawful, that it is simply the economic theory of the attorney-general in office, and not any definite legal standard, that is enforced upon business.

The history of the Sherman Act proves this. Attorney-General Olney, in 1893, speaking of the Sherman Act, declared that "as every business contract or transaction may be viewed as a combination which, more or less, restrains some particular kind of trade or commerce, any literal application of the provisions of the statute is out of the question." Attorney-General Harmon, in 1895, stated that combinations and monopolies "although they may be unlawful, control production and prices of articles in general use, and cannot be reached under this law." In the following year he declared that the Sherman Act must be amended "if any effective action is expected from this department," and added that the "indefiniteness" of the law "is a serious obstacle in the way of its prompt enforcement." Nevertheless, during the ten years just past, the theory of the law as laid down by Attorneys-General Olney and Harmon has been completely repudiated by Attorneys-General Knox, Bonaparte, Moody and Wickersham.

Coming to more recent history, Attorney-General Bonaparte, in 1907, declared that the acquisition of the Tennessee Coal and Iron Company by the United States Steel Corporation afforded no ground for action by the Department of Justice; and in his annual report for 1908, declared, after a full recital of the facts regarding a proposed increase of railroad rates, that it was "inappropriate and against sound public policy" and not in "conformity to the intent of Congress, appropriate on the part of this department, to utilize proceedings under the so-called Anti-Trust Law to prevent the application of said rates." In the twenty-six months that he was in office, Attorney- 
General Bonaparte began twenty-six prosecutions under the Sherman Act.

One month after he had left office, however, his successor, Attorney-General Wickersham, boldly announced a departure from this policy. Deploring that his predecessor had set to work with "newspaper clamor" to enforce the Sherman Act, and announcing that "some suits were instituted and some prosecutions commenced without sufficient consideration and without adequate cause," Attorney-General Wickersham declared that he would "be the last to authorize the institution of a criminal proceeding against men who, without intent to violate the law, have, nevertheless, acted in technical contravention of an extreme and a most drastic construction of that statute."

How far Attorney-General Wickersham departed from the policy of his predecessor, subsequent events soon showed. In 1910, he filed a petition under the Sherman Act against the Western Trunk Line Association, praying for an injunction to restrain the western railroads from advancing their rates-a complete repudiation of the deliberate determination that Attorney-General Bonaparte had announced two years before. In. 1911, he further emphasized his departure from Attcrney-General Bonaparte's policy by petitioning for the dissolution of the United States Steel Corporation on the ground, among others, that its acquisition of the Tennessee Coal and Iron Company was in violation of the Sherman Act.

How far Attorney-General Wickersham has abstained from that "newspaper clamor" and those "prosecutions commenced without sufficient consideration and without adequate ccuse" which he so deplored in the preceding administration; and whether in fact he has realized his ambition to "be the last to authorize the institution of a criminal proceeding against men, who, without intent to violate the law, have nevertheless acted in technical contravention of an extreme and a most drastic construction of that enactment" is a question which others may answer better than I. Judge Putnam, of the Federal Court in Massachusetts, suggested an answer, several weeks ago, when he threw out four of the five counts on which AttorneyGeneral Wickersham had procured the indictment under the Sherman Act of various officers of the United Shoe Machinery Company, saying that the statute "is practically so indefinite that criminal prosecutions like this at bar impose great hardship, 
by terrorizing very considerable portions of the community who have acted honestly through the possible peril of enormous fines and terms of imprisonment even for very many years." With a rebuke to the attorney-general for "exploiting all doubtful questions" under the Sherman Act by criminal proceedings, Judge Putnam added: "Under the circumstances, we are unable to understand why the Department of Justice directs, and the President permits, criminal proceedings like this."

This "terrorizing very considerable portions of the community who have acted honestly," to quote Judge Putnam, this "exploiting doubtful questions" by criminal proceedings, this expenditure of hundreds of thousands of dollars in secret espionage of thousands of business men at the behest of disgruntled competitors and irresponsible complainants, this flood of prosecutions initiated by special agents and special assistants-over whom the higher officials in the Department of Justice at best can exercise only cursory supervision,--this arbitrary enforcement upon business of economic theories peculiar to the particular incumbent of the office of attorney-general -theories frequently at variance with the policies that his predecessors, and some times he himself, had previously promulgated for the guidance of the business community, -all this is absolutely subversive of decent respect for law. How unnecessary all this is, the experience of other nations shows.

In Germany, there is no prohibitory legislation on the subject of trusts. No official has received letters of marque to harass at will the high seas of commerce and flaunt in every channel of business the terrors of anti-trust statutes. The national policy of the German Empire favors, in the utmost degree, combinations designed to prevent ruinous competition and to promote industrial efficiency.

"In no country in the world," writes the American Consul General at Berlin, "has there been greater development of trade combinations, understandings of one form or another, than in Germany. Trade combinations which have been in existence for many years are extending their influence, and new ones are constantly being formed."

These combinations, syndicates, or cartels fall into three classes: First, are the "selling agreements," under which manufacturers agree not to sell their product below a specified minimum price 
agreed upon by all the members of the cartel, and changing from time to time in accordance with the varying cost of production, and the general requirements of the market? Second, are the "sale syndicates," in which all members of the cartel pool their products for sale through a central committee, which not only fixes the selling price, but also apportions among the members the orders as they are received, according to the capacity of the various members, the quality of the goods ordered and the conditions of transport? Third are the "organized cartels," which include civil partnerships, commercial partnerships, "societies in commendam," "silent companies," stock companies, limited liability companies, and other corporate forms of organization which absorb and take up the shares of the constitutent concerns, issue new stock, and consolidate the whole management under the absolute control of a central authority?

In Germany there are no laws which impose upon combinations or cartels requirements in addition to the provisions of the general law applying to various forms of corporate organization. Thus, if a "selling syndicate" opens a central office for the sale of the products of its members, this office, like any other business house in the "commercial register," must be registered with the proper local authority and be subject to the general law governing corporations; but no other formality of any kind is required.

The result has been notably successful. Dr. Ernst von Halle, professor in the University of Berlin, an authority upon American industrial combinations and the author of "Trusts in the United States," declares:

I do not hesitate to say that, according to my opinion, Germany would be already in the midst of a dangerous industrial crisis but for the modifying and regulating influence of our cartels in most branches of production and distribution. The country, with its dense population and increasing capital that seeks employment, could not stand that reckless speculation that would result from unrestrained competition. Modern production, by means of steam-driven machinery, cannot stand unlimited competition, which too often leads to the destruction of the value of large capital. Machine production requires close technical regulation, and does not admit of economic anarchy. So the effect of cartels seems to have been to initiate a more harmonious industrial system, permitting promoters to invest their capital in many instances with ease and safety, where without combinations they might have been too timid to assume the risks of competition. The relatively low quotations of German consols and other public securities may be partly attributed to the great number of safe investments in cartelized industrial undertakings. 
- . Opposition to trusts has nowhere been made a plank of political platforms or been used in election contests. Among officials, scientists and lawyers, cartels are not considered unwholesome or objectionable per se. The Supreme Court of the Empire (Reichsgericht), in March, 1898, officially recognized the economic justification of combinations and their right to legal protection unless they use unlawful methods of checking competitors who decline to join them.

As Dr. von Halle intimates, the satisfactory condition of industrial combination in Germany in no small measure is due to enlightened German jurisprudence. The laws permit industrial development; and, by specific prohibition of improper corporate action and illegitimate trade practices, repress all that is actually vicious in industrial life. The German Civil Code provides that a transaction which offends against public morals shall be void. The mere existence of a combination, however, has repeatedly been held by the highest courts of the German Empire to be no offense against good morals. "When in a branch of industry," declares the Reichsgericht, "the price of a product falls too low, and the successful conduct of the industry is endangered or becomes impossible, the crisis which sets in is detrimental, not merely to individuals, but to society as a whole. It is in the interests of the community, therefore, that inordinately low prices should not exist in any industry for a long time. The legislatures have often, and recently, tried to obtain higher prices for products by enacting protective tariffs. Clearly, it cannot be considered contrary to the interests of the community, when business men unite with the object of preventing or limiting the practice of underselling, and the fall of prices. On the contrary, when prices for a long time are so low that financial ruin threatens the business men, their combination appears to be, not merely a legitimate means of self-preservation, but rather a measure serving the interests of the entire community. The formation of the combinations in question, therefore, has been designated in various quarters as a means which, if reasonably applied to national economics, is especially adapted to prevent uneconomic, unprofitable and catastrophic over production."

According to the decisions of the highest courts of the German Empire, any concern, be it a cartel or an independent establishment, which resorts to boycotting, misuse of corporate franchises, or the cutting of prices against competitors for the express purpose of bringing about their financial ruin, is guilty of an offense against good 
morals, in violation of the German Civil Code. No distinction, in the application of this rule, is observed between cartels and individual concerns; excepting, as the Supreme Court at Leipzig suggested, in 1904 , that cartels, by reason of their greater power, must be held to a particularly strict accounting for their methods.

In 1905, the Imperial German Government published statistics showing that three hundred and eighty-five cartels then existed in Germany, exclusive of cartels fixing conditions of business other than prices, and exclusive of numerous informal combinations, the existence of which had not come to the knowledge of the government. About twelve thousand concerns were shown to be members of these cartels. In the brick industry were one hundred and thirty-two cartels; in the iron industry were sixty-two cartels; in the chemical industry were forty-six cartels; in the textile industry were thirtyone cartels; in the coal mining industry were nineteen cartels, and in the quarry industry were twenty-seven cartels. Imperial Commissions, which studied the subject between 1903 and 1906, reported that in their opinion no legislation restricting or controlling industrial combination was necessary.

With what temper German statesmen approach the subject was revealed nine years ago when these Imperial Commissions were first proposed in the Reichstag. Count Posadowsky-Wehner, Imperial Vice-Chancellor and Minister of the Interior, declared that the Imperial Government took a position neither for nor against cartels; and that an Imperial Commission which should investigate cartels could result only in their interest. "The syndicate question," he declared, "has for a long time had such an important place in the economic life that the imperial administration has considered it a duty to observe the movement carefully. For the present, the imperial government takes a position neither for nor against syndicates."

In 1897, when the Coal Syndicate was renewed in the face of the serious difficulties that had greatly prolonged negotiations, Baron von Rheinbaben, for many years Prussian Minister of Finance, and recently President of the Rhine Provinces, announced: "To my great delight, I am able to tell you, for the tranquilizing of our whole industry, that the Coal Syndicate has been renewed." This declaration was received with applause by the Right, the Centre and the Left. "A war of competition," he declared in his budget speech 
"among all the separate concerns, each against the other, would be a state of things that we cannot wish to see revived."

The importance of industrial combination, in the fight for foreign markets, has always been realized by German statesmen. While the Imperial Commissions were conducting their investigations, Herr Moeller, Prussian Minister of Commerce, stated: "The problems connected with syndicates are difficult to solve, but to overthrow syndicates would destroy the ability of our country to compete abroad."

Herr Delbrueck, who succeeded him, and recently became Imperial Minister of the Interior, declared in the Reichstag in February, 1910: "In all measures planned to be taken against the syndicates, we must consider the fact that a non-syndicated German industry, a non-syndicated German banking system, would be powerless against syndicated foreign countries."

No abatement in official good-will toward industrial combination is discernible in Germany. In May, 1911, Herr Sydow, recently Prussian Minister of Commerce, declared that the Coal Syndicate had steadied prices and raised wages and added that "dissolution of the syndicate would result in social convulsions." In March, 1912, the Imperial Minister of the Interior emphatically expressed the same view.

The advantage which German industry derives from legislative tolerance and official good-will toward industrial combination, must inspire the envy of American business men. By a singular perversity, however, the features in the German situation which have been most loudly commended by American observers, have been a few spasmodic, unfortunate instances of governmental interference with German industry. Even with a well balanced legal system, which freely permits industrial combination and severely represses every improper and illegitimate corporate and trade practice, the beneficent results that naturally follow can, as German experience proves, be wholly lost when the government attempts arbitrarily to determine the direction of industrial development.

In 1893 the Coal Syndicate was reorganized, comprising ninetyfour per cent of the coal mines in Westphalia and the Rhine Provinces. After various vicissitudes, the syndicate was again reorganized in 1903, to include all the mines excepting a few independent con- 
cerns producing about $1,200,000$ tons annually. In the following year, the Prussian Government, which already owned a few mines, sought to force its way into the Coal Syndicate by purchasing control of the Hibernia mine, which was a member of the syndicate. The other members of the syndicate, fearful lest the entrance of the government into the industrial field "would close their industrial independence," prevented the government from accomplishing its purpose. At present, the mines outside the Coal Syndicate produce annually about $6,000,000$ tons, of which the mines of the Prussian Government produce about 2,000,000. The interest of the Prussian Government, as a coal producer, has recently led the Budget Committee of the Prussian Diet to adopt a resolution urging the government to join the coal syndicate. In answer to this resolution, Herr Sydow, Prussian Minister of Commerce, has informed the Prussian Diet that in determining upon its course, the government will be influenced by the allotment of production that the Coal Syndicate will be willing to assign to the government mines. To the private members of the Coal Syndicate this prospect is alarming; for by just such an entrance of the government into the industrial field was brought about the present condition in the potash industry.

From the first, the Prussian Government has been a leading member of the Potash Syndicate. Before 1883, the Prussian Government had erected state factories to manufacture the product of its potash mines, in order that it might strengthen its position to control prices. The Potash Syndicate, in that year, was extended until 1888, and Prussia, by virtue of its dominant position in the industry, obtained the right to veto any increase in the price of the product. Until 1909, by the terms of the syndicate agreement, the administrative powers of the syndicate were composed of the representatives of all the mines and factories. A selling agency, composed of two or three members, took charge of all the sales. All contracts were made through this agency, and the filling of the contracts was entrusted to the different members of the syndicate, who were paid directly by the consumers. Each member kept an account of the sums received, and from time to time the adjustment of receipts was made upon the basis fixed by the combination agreement. An increase of production could be compelled by the Prussian Minister of Commerce, after affording 
an opportunity for a hearing to the Executive Committee of the combination. The Executive Committee, in the first instance, could fix the price of the product; but the Prussian Minister of Commerce could veto any increase in price; and after hearing the Executive Committee, he could fix exceptionally low prices for German farmers. The Prussian Minister of Commerce generally exercised this right, so as to favor domestic agriculture at the expense of foreign trade, and to reduce the exportation of potash. By the terms of the syndicate agreement, the mine owners were compelled to deliver specified quantities of potash to the manufacturers, and were forbidden to sell outside the combination. The manufacturers, on the other hand, were required to observe the rules of the syndicate regarding prices and production. Private concerns in the syndicate were compelled to deposit Prussian securities in large amounts to guarantee the faithful performance of their agreements.

In 1909, when the old Potash Syndicate broke down, several private members made important contracts with American interests, at prices considerably lower than had previously been enforced by the syndicate. The Prussian Government, which was interested as a producer in the potash market, was affronted. In retaliation, Herr Sydow, Prussian Minister of Commerce, presented to the Bundesrath a bill requiring all mines to join the Potash Syndicate, and forbidding new mines to be opened for twenty years. When the bill went to the Reichstag, it contained a proposal for a compulsory governmental selling agency, which should have the monopoly of selling and exporting potash. In some degree, the governmental monopolistic character of the measure was modified by the-Reichstag. In the form in which it was passed in 1910, the Potash Law fixed the amount of production and the minimum price of the product, and provided that every two years the production of each concern must be redetermined, on the basis of the demand for the preceding years, and required that any concern producing more than its allotment must pay a prohibitive governmental charge.

In 1900, the old Potash Syndicate included only fifteen mines. In 1908, fifty mines were comprised within the syndicate. Since the Potash Law has gone into effect, the opening of new mines has been rushed, in order that the owners might come under the first 
general allotment of production that will determine the allotment of each mine for the succeeding five years. Over seventy-six mines are now subject to the operation of the Potash Law. In 1909, before the old Potash Syndicate expired, the Berlin Chamber of Commerce reported that the mines in the syndicate were working only at thirty per cent of their capacity and that $\$ 70,000,000$ more capital was invested in the business than the market requirements warranted. By the operation of the Potash Law, this unsatisfactory condition has been greatly aggravated.

German statesmen are conscious of these dangerous tendencies. Herr von Bethmann-Hollweg, when Minister of the Interior, wained the Reichstag against any general regulation of various syndicates. Numerous attempts that have keen made in the Reichstag to induce the government to undertake special legislation have been discouraged by the government. Herr Delbrueck, while Prussian Minister of Commerce, repeatedly deprecated such legislation on the ground that the whole subject was too mobile for governmental interference. As Imperial Minister of the Interior, he has repeatedly raised his voice against similar proposals. In the budget debates in 1911, and again in March, 1912, he has publicly deplored the proposal of a general law for the regulation of syndicates, and has expressed his firm conviction that the Potash Law has disappointed expectations. "The Potash Law," he recently declared, "does not encourage further experiments. We certainly did not wish it to be what, in practice, it has become."

In Great Britain, the tendency toward industrial combination has, in many trades, distanced both Germany and the United States. The history of the great thread combination of J. \& P. Coats is a classic in trust literature. Beginning in 1826, with a small mill of James Coats at Paisley, the business extended, under the guidance of three generations of able business men, until in 1890 it was turned over to the limited liability company of J. \& P. Coats, for $£ 15,750,000$. This combination comprised mills at Paisley, in England, and in Rhode Island. In 1895 and 1896, the combination acquired its chief rivals, with which it had for some time been allied through the Central Thread Agency, and attained control of sixteen plants in the United States, Canada and Russia, sixty branch houses, and one hundred and fifty depots. In 1897, fourteen firms, including plants located in France and Canada, combined to form the English 
Sewing Cotton Company, and made an alliance with J. \& P. Coats. In 1898, these allied concerns organized the American Thread Company, which acquired thirteen American firms. Since then the alliance has obtained control of the thread industry throughout the world. During the past year it has effected a combination with Belgian, Spanish, Austrian and Russian sewing thread factories, with a capitalization aggregating $£ 50,000,000$.

Similar combinations have existed in the iron and steel trade. When the famous International Rail Syndicate was formed in 1883, it included all but one of the eighteen British steel rail manufacturers, all but two of the German manufacturers and all the Belgian manufacturers. In 1904, to meet German competition, an agreement was made between the steel rail manufacturers of Great Britain, Germany, Belgium and France, by which the foreign trade was syndicated for three years, upon a basis which gave the various members specified portions of the market of the world. During the past year, twenty-three important steel concerns, who have suffered from a ruinously competitive market, have combined under the name of the English and Scottish Steel Makers' Association and, with the utmost frankness, have offered to all consumers a rebate of five shillings per ton on specified classes of material, provided the consumers purchase no material from manufacturers other than the members of the association. Whether this association will succeed is a question fraught with great interest to the entire steel industry in Great Britain.

Since the passage of the Sherman Act, such agreements and alliances have been condemned in the United States more bitterly than the ordinary single organization form of trust. The freedom with which such associations may be organized in Great Britain and the use of such associations to meet extraordinary, temporary trade conditions confirms the prophecy of a conspicuous English economist, who recently declared: "We may expect, in no very remote future, to see the iron industry governed by loose federations of great power, each large firm belonging to a number of associations according to the variety of its products; and there is a final possibility that these may unite into a general union."

The Industrial Commission of the United States found, in 1901, that aside from the sentimental hostility of a few radicals against industrial combination, "the strong feeling on the subject, which 
has been manifested for some years in the United States, seems to have found only a very faint echo in England." The explanation is that in Great Britain no statutes regarding industrial combinations have been enacted or even proposed, and the unwritten law of the courts, in deference to the economic changes of the time, has actually been relaxed. Scarcely four years after Congress had passed the Sherman Act, the House of Lords, sitting as the highest court in Great Britain, stated the law in consonance with modern economic development, and forever removed from British industry the economic terrors which in American business the Sherman Act has thrown about the phrase "restraint of trade." Lord Morris announced in the House of Lords the broadened view as follows:

The weight of authority up to the present time is with the proposition that general restraints of trade are necessarily void. It appears, however, to me that the time for a new departure has arrived, and that it should be now authoritatively decided that there should be no difference in the legal considerations which would invalidate an agreement, whether in general or partial restraint of trading. These considerations, I consider, are whether the restraint is reasonable and is not against public interest. In olden times all restraints of trading were considered prima facie void. An exception was introduced when the agreement to restrain from trading was only from trading in a particular place and upon reasonable consideration, leaving still invalid agreements to restrain from trading at all. Such general restraint was in the then state of things considered to be of no benefit even to the covenantee himself; but we have now reached a period when it may be said that science and invention have almost annihilated time and space. Consequently there should no longer exist any cast-iron rule making void any agreement not to carry on a trade anywhere. The generality of time or space must always be a most important factor in the consideration of reasonableness, though not per se a decisive test.

In Great Britain as well as in Germany coercion, force and fraud, which comprise all the methods by which monopolists try to accomplish their purposes, are specifically punished by definite, simple statutes. Corporation laws, so strict as to put ours to shame, compel fair dealing with investors and full publicity to stockholders and the state. Whether the offenders be great or small, they are all governed by the same law. This remedy, in Germany and in Great Britain, has proved a complete solution of the trust problem.

The trust policy of Germany and Great Britain clearly proves that wholesale prosecution and repression of industrial combination 
is not essential to healthful, economic, national development. The spectacle presented, it is said, in Chicago, after the jury had acquitted the beef packers of the charge of violating the Sherman Act, of a prominent governmental official bursting into tears, because the leaders of a great American industry had established their innocence of crime, has never, so far as can be found, been paralleled in any other civilized country in the world.

Germany and Great Britain illustrate the fact that laws specifcally directed against corporate fraud and illegitimate competitive practices afford adequate protection to every class in the community, and that industry and commerce can attain their normal and proper development only in so far as they are free from governmental and political interference.

Had the Sherman Act never been enacted, our economic condition undoubtedly would be better to-day than it is. Since, however, the Sherman Act is not likely soon to be repealed, and since we must live under it, we ought promptly to take heed from Germany and Great Britain, and as soon as possible divorce politics from the enforcement of this law.

The meaning of the Sherman Act will never be clearly and plainly defined until a long period of development and litigation has elapsed. Throughout this period, as the history of the act for twenty years has shown, any enforcement of the act by successive attorneysgeneral of the United States can be little more than the enforcement of the economic theories peculiar to whoever happens at the time to be attorney-general. No matter how highminded may be the incumbent of that office, his position in the administration must subject him to political exigencies, that cannot fail to influence his economic theories regarding business.

Germany and Great Britain prove that the best interests of the entire community are attained by laws prohibiting fraud and coercion, in corporate matters and in business competition, and by complete tolerance and non-interference by the government in respect to industrial combination. The Sherman Act professedly violates this principle. By it the United States has committed itself to the policy of interfering with the national, economic development, throughout that vast, undefined area, in which competition may possibly be affected. By condemning every contract and combination in "restraint of trade," the Sherman Act fixes practically no 
limit upon this policy of interference. To-day, the Sherman Act is a universal lettre de cachet, whose enormous powers are vested in the uncontrolled discretion of the Attorney-General of the United States.

The experience of mankind, no less than the experience of Germany and Great Britain already described, teaches that the economic theory which shall determine the industrial development of a nation must not be formulated hastily, nor by one man, but slowly, and by the steady growth and gradual agreement of national opinion. The Sherman Act expresses the determination of the United States to fix the limits beyond which trade shall not transgress. What these limits shall be is, to-day, as indefinite as were the duties of railroads under the first statutes which required them to serve everybody with adequate facilities, and at a reasonable price. Only time, experience and the evolution of enlightened public opinion can define the limitations intended by the Sherman Act. Certainly no single official, dependent upon the political exigencies of a political administration, can in the space of his brief incumbency in office determine for the whole nation, and for all time, the bounds which the American people, in the indefinite language of the Sherman Act, intended to fix for American industrial development.

An Interstate Trade Commission, having jurisdiction over all interstate trade and commerce, except transportation, and in other respects substantially similar to the Interstate Commerce Commission, has been earnestly recommended to Congress. Such a commission, of which all, or at least a majority of the members should be not lawyers but experienced business men, could work out the application of the Sherman Act to American industrial development, in much the same fashion that the Interstate Commerce Commission has worked out the application of the Interstate Commerce Act to American railroad development. This commission should be vested with the following powers:

1. All powers now vested in the Bureau of Corporations should be transferred to the Interstate Trade Commission. This should include the power to investigate and require reports from concerns now engaged in interstate trade and commerce.

2. Persons, firms and corporations proposing to enter into any contract or combination affecting interstate trade or commerce should have the right to apply to the Interstate Trade Commission 
for an order determining whether the proposed contract of combination is in violation of the Sherman Act. The order of the Interstate Trade Commission should be subject to review in the District Court or the Commerce Court on application of any party in interest or on application of the government. Until reversed by the court the order of the Interstate Trade Commission should be effective. All acts done in pursuance of and before the reversal of any contract or combination should be deemed lawful and not in violation of the Sherman Act.

3. The disintegration and reorganization of all combinations adjudged to be in violation of the Sherman Act should be carried out under the orders of the Interstate Trade Commission. These orders should be subject to the conditions above described. The voluntary disintegration and reorganization of combinations in obedience to the Sherman Act, it may be noted, could be carried out under the orders of the Interstate Trade Commission pursuant to its powers described in the previous paragraph.

4. The prosecution of any person, firm or corporation by the Department of Justice under the Sherman Act should be commenced only after the Interstate Trade Commission shall have made an order recommending such prosecution. This order, however, need not be subject to review in the District Court or the Commerce Court.

This commission, like the Interstate Commerce Commission, should be non-partisan, non-political and substantially permanent.

By the establishment of such a commission, the administration of the Sherman Act and the governmental control of industrial combination would be divorced from politics, a government of laws would be substituted for a government of successive attorneysgeneral of the United States-heretofore often inharmonious with each other, and frequently inconsistent with themselves-and the industrial peace, for which we have cause to envy Germany and Great Britain, would finally be ours. 